\title{
女子大学生の深夜行動の特街
}

\author{
吉岡 朋子，風間 健
}

武庫川女子大学生活環境学部

\section{Characteristics of Daily Activities at Late Night of Female Students}

\author{
Tomoko YOSHIOKA and Ken KAZAMA
}

Mukogawa Women's University,6-46 Ikebiraki-cho,Nishinomiya-shi,663-8558,Japan

\begin{abstract}
Many goods and services at late night have appeared in the market.Therefore,the objective of this study was to clarify the characteristics of daily activity at late night of young people who were active at late night.

The method of this study was to survey the daily activity of female student from 10p.m. to 5a.m. the next day on weekdays and holidays. The main results were as follows.

(1)The difference among samples had stronger influence on the obtained data than the difference within samples.

(2)The time of activities at late night was longer in students than in whole Japanese.On the rate of samples who were astir at late night,holidays was twice rate of weekdays.

(3)The correlation of between bedtime and each item of daily activities for a whole day was high in the items of the free time,low in the items of the bound time and half in the indispensable time. The correlation between weekdays and holidays was also found.

(4)Activities at late night were classified to five factors. The characteristics of each factor depended on the types of communication's media,for example,telephone and communication.

(5)The activities, which were mostly active in late night,were telephone,computer and rest.Contrary,the items of low rate of activity at late night were work and transportation.

(6)The correlations among activities were found.The character of samples related to transportation were clarified.Their character was self-assertive and aggressive.
\end{abstract}

Keywords: Daily activities, Late night,Female students

\section{1. 緒带}

\section{1. 生活時間}

本報告は生活時間に基づいて,女子大学生の樑夜行動の特徵 を求める. 生活時間調查は, 被験者に生活行動をすべて時間と ともに記載させ, そのデータを解析する. 生活行動として記載 される項目は, あらかじめ与えている.

これら生活行動項目は, NHKにより必需行動, 拘束行動, 自 由行動に大別されている[注 1]. 必需行動は睡眠などの整理行 動, 拘束行動はバイト, 学業などの社会行動が含まれる. 自由 行動は趣味やテレビ, 休息などが含まれる. 必需行動, 拘束行 動は意識的に計画された行動が多いが, 自由行動は熱中してい つのまにか時間が経ったとか, ダラダラとテレビを見てしまっ たというような「時間を意識しない」または，「理性的でない」 行動が多い.

このように自由行動時間は非論理的に過ごされることが多 いので, 感性に基づく行動と考えられる. 本報告で述べるよう に, 深夜行動はほとんどが自由行動なので, 感性型の時間の過 し方が多くを占める.

\section{2. 従来の研究}

日本人の睡眠時間は年々减少し, 国民全体平均の平日でみる
と，1970年が 7 時間 57 分であったのが， 2000 年には 7 時間 23 分となった [注 2,3$]$. 大学生はもともと睡眠時間は少なかっ たが，1970年の 7 時間 24 分に対して 2000 年は 7 時間15分で，国 民全体と同様に减少している[注 2].その理由は就寝時間が遅 くなったためで, 起床時間は余り変わらない[注 4$]$. また, 就 寝時間が遅くなると,生活様式に大きな影響を与えることが報 告されている[注 5$]$ ．このような影響は性別・年齢を問わずす べての層にみられ[注 4 ，高校生や高齢者の夜型化がみられる が, 特に20歳前後の若者では深夜の行為者増加が顕著であると 報告されている[注 1,6$]$.

\section{3. 目的}

前述のように若者の深夜の行動が増加している.しかし, 深 夜行動は日中の行動に比べ, 自由行動が多いと予想され, 個人 差も大きいので複雑である.

一方, コンビニエンスストアやドンキホーテのような深夜営

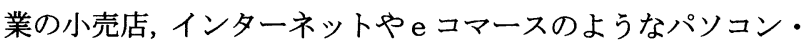
コンテンツなど, 深夜も利用できる商店, サービスが増加して いる. したがって, トレンドリーダーである若者の深夜行動の 特徴を知れば,ささに新しいマーケットの予測も可能と考えら れる。 


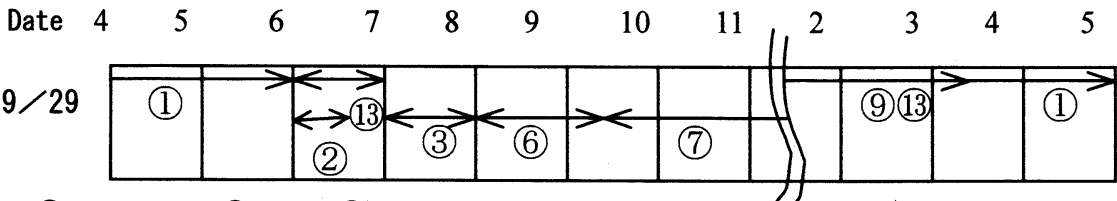

(1) sleeping (2)meal (3)dressing (4)work (5)household (6)transportation (7) study (8)bathing (9hobby (11)shopping (11)communication (12)phone (13) television(TV) (14)music (15)reading (16)computer (17)rest (1B)others

Fig. 1: An instance of questionnaire[example]
炊事, 掃除など. 移動 : 通学, バイトの往復, ドライブなど. 学業 : 大学での講義, 予習, 復 習, 試験勉強, 学校行事など. 入浴 : 洗髪, 入浴. 趣味 : ゲー ム, コンサート, 映画, 犬の散 歩, けいこごと, 観賞など. 交 際 : おしやべり, カラオケ, 家 族・友人・知人とのつきあい.

電話 : 携帯電話, 自宅電話での

そこで本報告では, 20 歳前後の若者である女子大学生につ いて, 深夜型の生活行動に着目し, 深夜行動の特徴を探るこ とを目的とする. 夜 10 時から朝 5 時までを哚夜 (労働基準法 で深夜と定義されている時間）とし, 各時間带の行為内容, 行為時間を休日と平日に分けて調查し, 行為の特徴を明らか にする. また被験者を深夜行動の特徴別にグループ化し, 深 夜行動に積極的な被験者の性格を示す.

これらの結果によって, 若者の梁夜行動の特質を明らかに することを目的とする.

\section{2. 方法}

\section{1 . 生活時間調查}

調查期間：1999年 9 月 28 日〜 10 月 19 日

調查対象 : 武庫川女子大学生活情報学科 1 回生

有効標本数: 平日 3 日間と休日 2 日間, 調查対象者 102 名に ついて調査し, 計 510 票の有効データを得た.

調查内容: 調查用紙は時刻日記目盛式とし, 朝起きてから, 眠るまでの行動を Fig.1 の 18 項目に分け, 回答用紙に時間ご とに記入させた. 次に調查時示した各項目の内容を列举した. 睡眠 : 30 分以上連続した睡眠, 仮眠, 昼寝. 食事 : 朝食, 昼 食, 夕食, 夜食. 身支度 : トイレ, 洗顔, 化粧, 着替え, 美 容院, エステなど. バイト：なんらかの収入を得る行動, 準 備, 片付け含む. アルバイト. 家事 : アイロンがけ, 洗濯,

Table1: Average time of each action (hour)

\begin{tabular}{|c|c|c|c|c|c|c|}
\hline \multirow{2}{*}{ item } & \multicolumn{4}{|c|}{ female students } & \multicolumn{2}{|c|}{ all Japan[note6] } \\
\hline & holic & & weekd & & hol iday & weekday \\
\hline sleeping & 4.17 & *** & 4.25 & *** & 5.45 & 5.50 \\
\hline meal ${ }^{* *}$ & 0.21 & ** & 0.42 & ** & 0.03 & 0.04 \\
\hline dresshing & 0.21 & & 0.25 & & - & - \\
\hline work & 0.01 & & 0.12 & & 0.10 & 0.16 \\
\hline household & 0.16 & & 0.19 & $*$ & 0.08 & 0.09 \\
\hline transportation & 0.38 & $* *$ & 0.27 & ** & 0.02 & 0.03 \\
\hline study & 0.15 & $*$ & 0.23 & $* *$ & 0.06 & 0.07 \\
\hline bathing & 0.47 & & 0.51 & & - & - \\
\hline hobby & 0.36 & $*$ & 0.43 & $* *$ & 0.14 & 0.09 \\
\hline shopping & 0.00 & & 0.01 & & - & \\
\hline communication & 0.95 & $* *$ & 1.14 & $* *$ & 0.08 & 0.04 \\
\hline phone & 0.43 & & 0.55 & & - & - \\
\hline TV & 0.99 & ** & 1.02 & $* *$ & 0.60 & 0.58 \\
\hline music** & 0.45 & $* *$ & 0.71 & $* *$ & 0.03 & 0.04 \\
\hline reading & 0.36 & $* *$ & 0.45 & ** & 0.02 & 0.12 \\
\hline computer & 0.27 & & 0.21 & & - & - \\
\hline rest & 0.38 & ** & 0.32 & $* *$ & 0.05 & 0.05 \\
\hline
\end{tabular}

通話. ショッピング : 買い物, ウィンドーショッピングを含 む. テレビ : テレビをみる, BS, CS, CATV の視聴を含む,

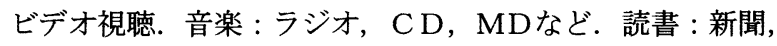
雑誌 (週刊誌・月刊誌), 小説, マンガ, カタログなどを読む. コンピュータ：インターネット，メール，ワープロ，コンピ ュータゲームなど．休息：休鄎，特に何もしていない状態. その他：上記項目に該当しない行為.

Fig. 1 中の数字は 18 項目にそれぞれ割り当てた数字であり， 例えば(1)は睡眠を表し，午前 4 時から午前 6 時まで睡眠を行 っていたことを表す．同様に(2)は食事，1313テレビ視聴を表 しており, 午前 6 時から午前 6 時 30 分まで食事をしながらテ レビを見て, 午前 6 時 30 分から午前 7 時まではテレビを見て いたことを表している. 午前 6 時から 6 時 30 分までのように, 複数の行為を同時に行うことを「ながら行為」と呼ぶ.

\section{2. 性格調查}

調查期間 2001 年 6 月 20 日

調查対象 武庫川女子大学生活情報学科 1 回生 有効票数 120 票

調查内容 4.5.で選んだ 4 項目について, まずそれぞれの項目 を「重視する, やや重視する, どちらともいえない, やや軽 視する，軽視する」という5段階の一つを選択させる調査を 行い, 重視 (やや重視含む) と, 軽視（やや軽視含む）と回 答したデータを分析に用いた.

次に性格の調査は，それぞれ友人にどのような性格と言われ るかを複数選択で回答してもらった．性格を表す項目は， Table7 に出てこなかったもののみ挙げると, 保守的, クール, 気分屋, 大人, 短気, のんき, 悲観的, 温厚, 薄情, 協調的, 孤立的, 社交的, 内向的, 明るい，暗い，しつこい，おおら か, 細かい, 静か, にぎやか, 常識的, 非常識, 柔軟, 気が 強い, その他であり, 表中に登場したものを含めると全部で 34 項目である.

\section{3. 結果}

\section{1. 平均行為時間}

深夜行動について Table 1 の結果を得た. データの右列は全 国平均行為時間, 左列は本報告の女子学生の平均行為時間で ある. 表中の項目横の「**」は，休日と平日の平均行為時間 に有意差が $1 \%$ であったことを表している．有意差は $\mathrm{t}$ 検定 により求められ，「**」は，食事と音楽のみに付された．単位 は時間を 10 進法で表している. また, 全国平均行為時間は, 


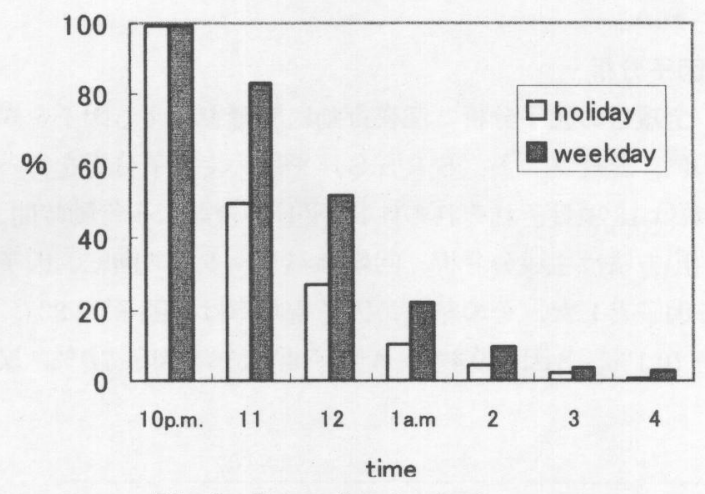

Fig. 2: Rate of not slept person (hol iday and weekday)

『国民生活時間調查』 ${ }^{4)}$ の深夜の平均行為時間を示している. また，本報告と全国の平均值に有意な差があったものには， 表中の本報告欄の平均行為時間の横にマーク(**: $1 \%$ 有意, *: $5 \%$ 有意）をつけて示した. 例えば睡眠では, 休日平日と もに「**」が付されており，本報告と全国平均の間に有意な 差があることを示す.

本報告では女子大学生の特徴を探るため, NHKのデータ ブックにない項目をいくつか設けているため, 比較できない 項目があり，これらを表中に「一」で示した.

Table1 では, 女子大学生と全国平均の項目が対応している もの (一を含まないもの) が 12 項目ある. そのうち有意な差 を生じた 11 項目中で, 睡眠を除く 10 項目は, 全国の平均時 間に比べ, 本報告の被験者の方が深夜の平均行為時間が長い. これより学生は, 生活行動の深夜化を考察する対象として適 当であることがわかる.

\section{2. 起床者率}

休日と平日の毎正時の起床者率（全体に占める, 起きてい る人の割合）を求めた（Fig.2). Fig.2 より，休日は平日より 起きている人の割合が高く, どの時間も約 2 倍でに近かった. これより休日は平日より深夜化が進んでいるといえる.この

Table2: Result of variance analysis. (Fvalue)

\begin{tabular}{c|ll}
\hline item & holiday & weekday \\
\hline sleeping & $2.069^{* *}$ & $1.732^{* *}$ \\
meal & $2.207^{* *}$ & $2.573^{* *}$ \\
dressing & $1.808^{* *}$ & $1.817^{* *}$ \\
work & $2.883^{* *}$ & $1.365^{* *}$ \\
household & 0.908 & $3.092^{* *}$ \\
transportation & $1.443^{* *}$ & $4.787^{* *}$ \\
study & $2.117^{* *}$ & 1.228 \\
bathing & $1.711^{* *}$ & $2.610^{* *}$ \\
hobby & $2.295^{* *}$ & $1.929^{* *}$ \\
shopping & $1.401^{* *}$ & $1.443^{* *}$ \\
communication & $2.851^{* *}$ & $3.227^{* *}$ \\
phone & $1.826^{* *}$ & $1.468^{* *}$ \\
TV & $3.464^{* *}$ & $2.959^{* *}$ \\
music & 1.338 & $2.668^{* * *}$ \\
reading & 1.262 & $1.810^{* *}$ \\
computer & $8.339 * *$ & $1.702^{* *}$ \\
rest & 1.190 & $2.406^{* *}$ \\
others & 0.000 & 1.199 \\
\hline
\end{tabular}

原因として, 休日は起床時間が遅く（平日 7.36 時起床に対し 休日は 8.72 時起床) 睡眠が充足していること, 交際, 趣味な どを平日より長く行っているため, 就寝時間が遅くなってい ることなどが考えられる.

\section{4. 考察}

\section{1. 個人データの扱い方}

全調查日の行為時間のデータを，個人別の平均值を用いる か, 個人の個々の值のまま用いるかを決める，それには調査 した全日数の行為時間のばらつきを個人別に求め, 個人間の ばらつきのほうが大きければ個人別の平均值を用い，個人内 のばらつきのほうが大きければ平均せずに個人の行為時間を 求める.これを次の分散分析により求めた。

データは個人の平日 3 日間, 深夜行動の行為時間とした. Table2 にその結果を示す．F値とは，個人平均間平方を個人 内平方で除した值である.個人間の影響のほうが大きい場合， $1 \%$ 有意を「**」で，5\%有意を「*」で示した．その結果， Table2 で見るように有意な項目が多かったので, 個人内の影 響より個人間の影響を多く受けていることを知った。そこで 以降は, 個人毎の行為時間を平均したものをデータとした.

\section{2. 就寝時間に及ぼす終日の生活行動の影響}

就寝時間の遅速が終日の生活行動により定まるかを知る ために, 各項目の行為時間と就寝時間の相関関倸を調べた. データは休日と平日の合計時間を用いた. 結果を Table3 に示 す.これらの項目間に相関があったのは自由行動に属する項 目に多く, 拘束行動に属する項目は無く, 必需行動に属する 項目は半々となった. その理由は, 拘束行動の項目は昼に行 われる行為が多く, 自由行動は深夜に行われる行為が多いた

Table3: Result of correlation analysis (bedtime and each item of daily activities )

\begin{tabular}{lll|lll}
\hline \multicolumn{1}{c}{ Item } & $\mathrm{r}$ & & \multicolumn{1}{c}{ item } & $\mathrm{r}$ \\
\hline I meal & .053 & $\mathrm{~F}$ & shopping & .034 \\
I dressing & $.093^{*}$ & $\mathrm{~F}$ & communication & $.136^{* *}$ \\
B & Work & .013 & $\mathrm{~F}$ & phone & .164 \\
$\mathrm{~B}$ & household & .030 & $\mathrm{~F}$ & television & -.053 \\
$\mathrm{~B}$ & transportation & .069 & $\mathrm{~F}$ & music & .093 \\
$\mathrm{~B}$ & study & -.037 & $\mathrm{~F}$ & reading & -.045 \\
I bathing & -.064 & $\mathrm{~F}$ & computer & $.126^{* *}$ \\
$\mathrm{~F}$ & hobby & $.139^{* *}$ & $\mathrm{~F}$ & rest & $-.114^{* *}$ \\
\hline I: indispensable time, & B:bound time, F:free time
\end{tabular}

Table4: Result of correlation analysis (hol iday and weekday)

\begin{tabular}{ll|lc}
\hline \multicolumn{1}{c}{ item } & $r$ & \multicolumn{1}{c}{ item } & $r$ \\
\hline meal & $.444 * *$ & shopping & -.015 \\
dressing & $.583 * *$ & communication & $.376 * *$ \\
work & $.393 * *$ & Phone & $.221 *$ \\
household & .147 & television & $.387 * *$ \\
transportation & $.388 * *$ & Music & $.411 * *$ \\
study & .168 & reading & .176 \\
bathing & $.678 * *$ & computer & $.635 * *$ \\
hobby & .093 & rest & $.290 * *$ \\
\hline
\end{tabular}


めと考えられる (4.4.に詳細)。すなわち就寝時間は昼型の行 為からは影響を受けず，夜型の行為により定まると言えた。 自由行動の中でテレビが有意でないのは昼も見ているから

(Fig.3 参照), 必需行動が半々なのは昼型と夜型に分かれる からである.

また, 休日の就寝時間と平日の就寝時間の相関を調べた結 果， 0.408 で $1 \%$ 有意であった.つまり，全員の中で休日早 寝な人は平日も早寝, 休日遅寝な人は平日も遅寝という傾向
が見られた。

\section{3. 因子分析}

（1）全項目の因子分析：深夜行動に影響を与える因子を知 るために, 統計ソフト（S P S S ）を用いて因子分析を行っ た.変数は 18 項目それぞれの休日・平日の合計深夜行動時間, 因子抽出方法は主成分分析, 回転はバリマックス回転, 因子 数は 5 因子とした。 その結果，因子寄与率は 1 因子 $12.8 \%$, 2 因子 $10.1 \% ， 3$ 因子 $9.4 \% ， 4$ 因子 $8.4 \% ， 5$ 因子 $7.7 \%$, 累

Table5: Result of factor analysis

\begin{tabular}{|c|c|c|c|c|c|c|c|}
\hline factor & \multicolumn{5}{|c|}{ factor } & \multirow{2}{*}{\multicolumn{2}{|c|}{ meaning }} \\
\hline item & 1 & 2 & 3 & 4 & 5 & & \\
\hline work & .66 & & & & .16 & & \multirow{4}{*}{ uncommunication tyipe } \\
\hline meal & .63 & .43 & & .35 & -.11 & & \\
\hline transportation & .53 & -.11 & -.29 & & .50 & 1 & \\
\hline Rest & -. 53 & .44 & .30 & & .28 & & \\
\hline computer & & .62 & -.20 & & -.25 & \multirow{2}{*}{2} & \multirow{2}{*}{ net commu. type } \\
\hline dressing & & -.55 & & & -.11 & & \\
\hline TV & .12 & -.31 & .73 & & -.31 & \multirow{2}{*}{3} & \multirow[b]{2}{*}{ mass commu. type } \\
\hline reading & & & -.66 & & -.18 & & \\
\hline communication & .15 & & & .86 & & \multirow{2}{*}{4} & \multirow{2}{*}{ facing commu. type } \\
\hline bathing & .31 & .39 & .26 & -.62 & & & \\
\hline Phone & .11 & & & & .79 & 5 & unfacing commu. type \\
\hline
\end{tabular}

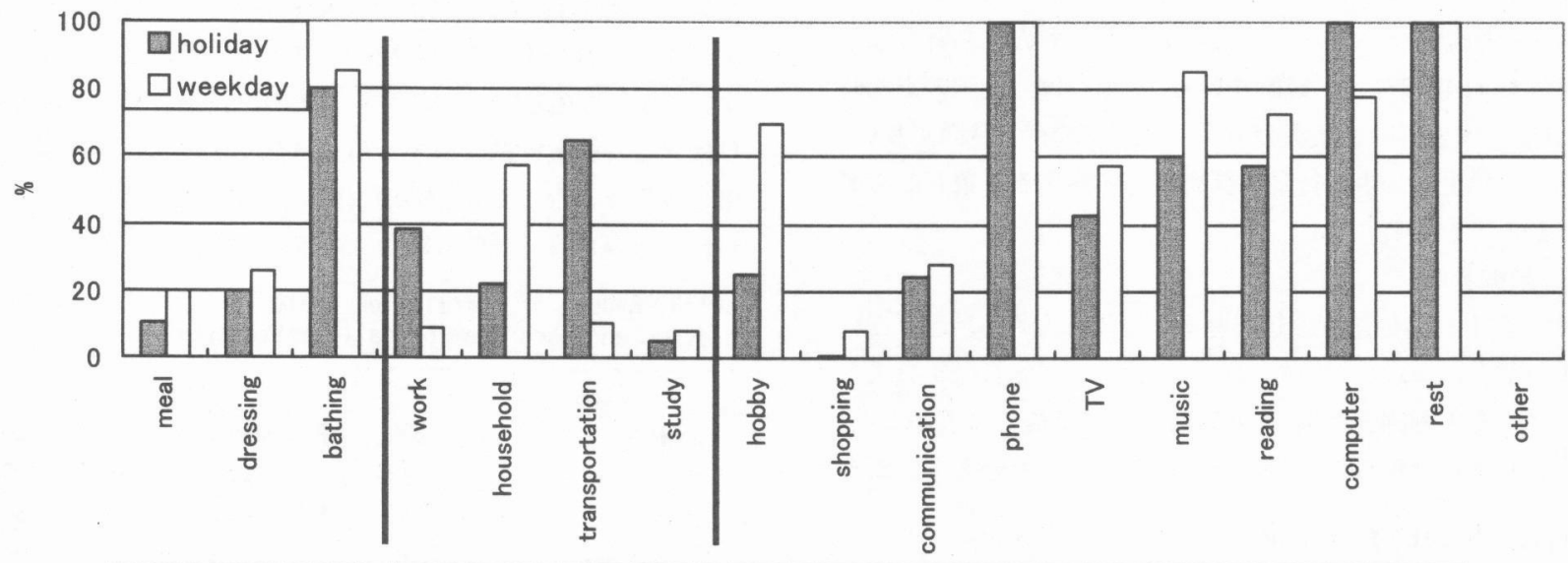

\begin{tabular}{|c|c|}
\hline $\begin{array}{c}\text { indispensable } \\
\text { time }\end{array}$ & free time \\
\hline
\end{tabular}

Fig.3:Rate of activity at late night (holiday and weekday)

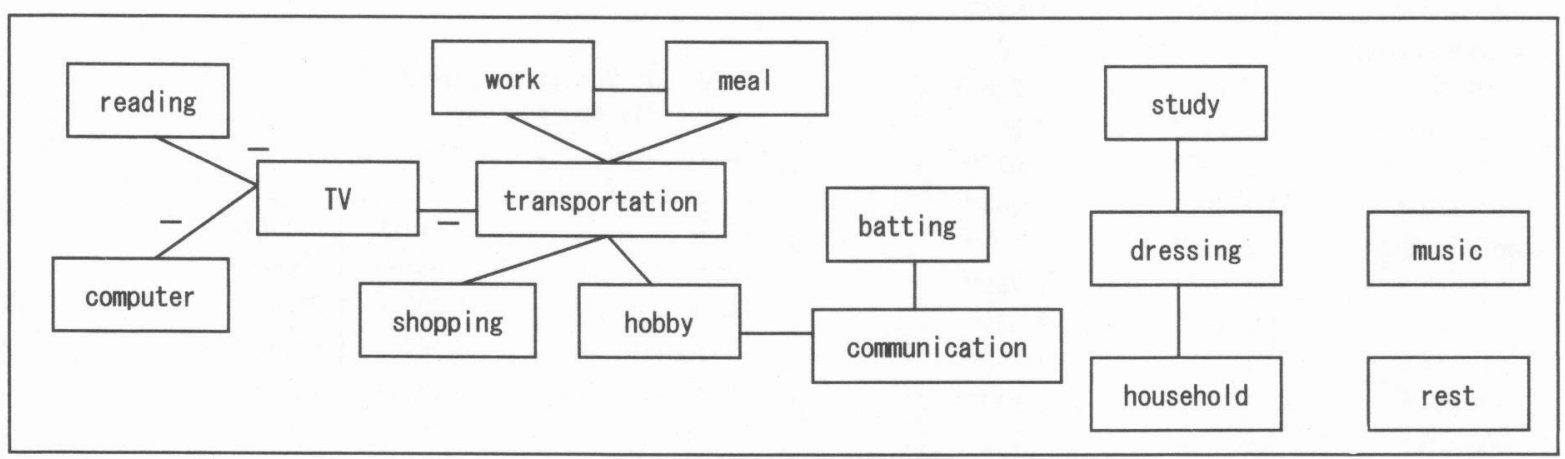

Fig. 4: Model of correlation 
積 48.4\%であった．累積寄与率が低いが，これは 18 項目間の 深夜行動時間の間の相関が低かったためであった.

（2）選択された項目の因子分析：（1）では因子分析の因子 寄与率が低かったが，その理由を休日・平日に差が大きい項 目があり，それも含めた合計時間を用いたので, 各項目の特 徵が薄められたためと考えた。 そこで休日と平日の間に差が 見られない項目を選び出すため, 各項目について, 休日と平 日の梁夜の行為時間の相関係数 $(r)$ を求めた (Table4). Table4 中の「**」は $1 \%$ 有意で,「*」は $5 \%$ 有意で相関があった.

食事と音楽に関しては相関があるが平均值にも差があった (Table1). それ以外の 9 項目は, 相関もあり平均值も差が ない. これより, 変数を休日と平日の行動時間の間で相関の あった 11 項目とし, 改めて因子分析を行った. 因子抽出方法 は主成分分析, 回転はバリマックス回転, 因子数は 5 因子と した. その結果, 累積寄与率が 3 因子: $40.5 \%, 4$ 因子:50.8\%, 5 因子：60.2\%となり前回より向上した。 6 因子以下は寄与 率が低いと考えられ，項目を 5 因子で表すことにした。この 場合の因子寄与率は 1 因子 $15.5 \%, 2$ 因子 $13.1 \%, 3$ 因子 $11.9 \% ， 4$ 因子 $10.3 \% ， 5$ 因子 $9.4 \%$ であった.

因子分析の結果を Table5 に示す. Table5 において, 少数以 下 1 桁でゼロの因子負荷量は空欄とした. 1 因子はバイト， 食事, 移動がプラスで，休息がマイナスであった．このこと から，1因子は情報行動以外が影響する非コミュニケーショ ン型とした． 2 因子はコンピュータがプラスで身支度がマイ ナスであり，ネットワークコミュニケーション型とした． 3 因子は, テレビがプラス, 読書がマイナスであることより, マスコミュニケーション型とした４４因子は交際がプラス，
入浴がマイナスなので, 対面コミュニケーション型とした. 5 因子は電話がプラスであることより非対面コミュニケーシ ヨン型とした. このように, Table5 の，2因子以降はいずれ も情報行動がプラスに表れており，この共通性に着目して梁 夜の生活を情報行動の種類で分類した。

\section{4. 深夜行動率}

行動時間帯が深夜に集中している行為や, 深夜に行われな い行為, またそれらの休日, 平日の違いなどの特徴を知るた めに, 深夜行動率 [（深夜の行動時間／終日の行動時間） $\times$ 100]を求めた（Fig.3).

グラフより, 電話, 休息は休日・平日とも, コンピュータ は休日に, 哚夜行動率が $100 \%$ であった. アンケートは 5 分 を超えて続けた行動を記入させているため，5分以下の短い 通話やメールでの利用は, 行為時間には記入されなかった. つまり電話は，5分を超える通話に関しては深夜のみに行わ れていることがわかった. これより電話, コンピュータ, 休 息は，主に夜に行う行為の代表的項目であるといえる.

また, 平日と休日とで特に差が大きかったのは, 学業であ った. 平日は, ほとんどの学生が大学で講義を受けており, 終日での学業時間は長い. それに対して休日は学業が少なく 家庭で勉強していないことがわかった. また, 趣味は平日に は深夜しか行う時間が無いためか, 休日より梁夜行動率が高 い. 移動, 学業, コンピュータ以外は平日のほうが休日より 樑夜行動率が高く, 休日は日中時間にゆとりがあるためか, 媣夜行動率が低かった. 媣夜行動率のとくに低い項目は, バ イト, 移動, 平日学業, ショッピングであった. バイト, 移 動, ショッピングについては女性であることから, 深夜に行

Table6: Result of correlation analysis (activities at late night)

\begin{tabular}{|c|c|c|c|c|c|c|c|c|c|c|c|c|c|c|c|c|c|}
\hline item & $=$ & 焉 & $\begin{array}{l}\stackrel{\infty}{\subseteq} \\
\dot{s} \\
\& \\
\Phi \\
\frac{1}{0}\end{array}$ & 믐 & $\begin{array}{l}\frac{0}{0} \\
\frac{0}{0} \\
0 \\
0 \\
0 \\
\text { 인 }\end{array}$ & 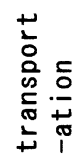 & $\underset{i=}{\stackrel{\lambda}{0}}$ & 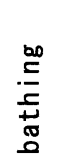 & $\begin{array}{l}\text { ㅇ } \\
\text { 응 }\end{array}$ & $\begin{array}{l}\text { a } \\
\frac{\text { co }}{0} \\
\text { 응 } \\
\frac{}{\infty}\end{array}$ & 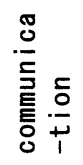 & $\begin{array}{l}\stackrel{0}{\frac{1}{2}} \\
\text { 음 }\end{array}$ & 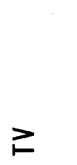 & $\frac{0}{0}$ & 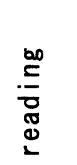 & 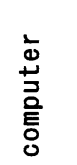 & 苾 \\
\hline meal & 45 & 1.000 & -.105 & .230 & .119 & $\begin{array}{r}.237 \\
*\end{array}$ & -.055 & .103 & .161 & -.025 & $\begin{array}{r}.254 \\
*\end{array}$ & .033 & -.047 & .036 & .009 & .094 & -.059 \\
\hline dressing & 39 & -.105 & 1.000 & .024 & $\begin{array}{r}.279 \\
* *\end{array}$ & .051 & .195 & -.053 & .083 & .193 & .079 & -.018 & 156 & -.015 & -.046 & -.065 & -.102 \\
\hline work & 16 & $\begin{array}{r}.230 \\
* \\
\end{array}$ & .024 & 1.000 & .141 & $\begin{array}{r}.215 \\
* \\
\end{array}$ & -.167 & .070 & .133 & .078 & .031 & .161 & .072 & -.032 & .008 & -.067 & -.068 \\
\hline household & 22 & .119 & $\begin{array}{r}.279 \\
* *\end{array}$ & .141 & 1.000 & -.102 & .054 & -.003 & .030 & -.063 & .135 & -.028 & .142 & -.005 & -.019 & .088 & .036 \\
\hline transportation & 39 & $\begin{array}{r}237 \\
* \\
\end{array}$ & .051 & $\begin{array}{r}.215 \\
* \\
\end{array}$ & -.102 & 1.000 & -.162 & .118 & $\begin{array}{r}223 \\
*\end{array}$ & $\begin{array}{r}202 \\
*\end{array}$ & .027 & $\begin{array}{r}.208 \\
*\end{array}$ & $\begin{array}{r}-.212 \\
* \\
\end{array}$ & .044 & .013 & -.086 & -.185 \\
\hline study & 22 & -.055 & $\begin{array}{r}.195 \\
*\end{array}$ & -.167 & .054 & -.162 & 1.000 & .080 & -.120 & -.056 & -.119 & -.171 & .000 & .066 & .017 & -.084 & .053 \\
\hline bathing & 79 & .103 & -.053 & .070 & -.003 & .118 & -.080 & 1.000 & -.182 & .024 & $\begin{array}{r}-.237 \\
*\end{array}$ & .084 & .083 & -.044 & -.018 & .105 & .072 \\
\hline hobby & 24 & .161 & .083 & .133 & .030 & .23 & 120 & -.182 & 1.000 & .140 & $\begin{array}{r}.289 \\
* *\end{array}$ & .018 & -.087 & .174 & .017 & .003 & -.050 \\
\hline shopping & 3 & -.025 & .193 & 078 & -.063 & $\begin{array}{r}.202 \\
*\end{array}$ & -.056 & .024 & .140 & 1.000 & .060 & -.048 & -.128 & .051 & .188 & -.056 & -.005 \\
\hline communication & 67 & $\begin{array}{r}.254 \\
* \\
\end{array}$ & .079 & .031 & .135 & .027 & -.119 & $\begin{array}{r}-.27 \\
*\end{array}$ & $\begin{array}{r}.280 \\
* *\end{array}$ & .060 & 1.000 & .058 & .038 & 104 & .056 & .030 & -.008 \\
\hline phone & 49 & .033 & -.018 & .161 & -.028 & $\begin{array}{r}.208 \\
*\end{array}$ & -.171 & .084 & .018 & -.048 & .058 & 1.000 & -.054 & .193 & -.038 & -.006 & .021 \\
\hline TV & 83 & -.047 & .156 & .072 & .142 & $\begin{array}{r}-.212 \\
*\end{array}$ & .000 & .083 & -.087 & -.128 & .038 & -.054 & 1.000 & -.025 & $\begin{array}{r}-.201 \\
*\end{array}$ & $\begin{array}{r}-.208 \\
*\end{array}$ & -.063 \\
\hline music & 56 & .036 & -.015 & -.032 & -.095 & .044 & .066 & -.044 & .174 & .051 & .101 & .003 & -.025 & 1.000 & .148 & -.011 & -.009 \\
\hline reading & 46 & .009 & -.046 & .008 & -.019 & .013 & .017 & -.018 & .017 & .188 & .056 & -.038 & $\begin{array}{r}-.201 \\
*\end{array}$ & .158 & 1.000 & .054 & -.059 \\
\hline er & 18 & .094 & -.065 & 067 & .088 & -.086 & -.084 & .105 & .003 & -.056 & .030 & -.006 & $\begin{array}{r}-.208 \\
*\end{array}$ & -.011 & .054 & 1.000 & .029 \\
\hline rest & 36 & -.059 & -.102 & -.168 & .036 & -.185 & .053 & .072 & -.050 & -.005 & -.008 & .021 & -.063 & -.009 & -.059 & .029 & 1.000 \\
\hline
\end{tabular}


うことを控えていると考えられるが，平均時間でなく個々の 1 日の行為時間で調べると, 樑夜に行っている人は存在する.

また, 行動別に見ると, Fig.3より必需行動, 拘束行動に比 べ, 自由行動の梁夜行動率が高い. 自由行動が多く行われる ことは，緒言でも述べたように，時間を意識しない，つまり 感性型の行動が深夜に多いことを表している.

\section{5. 項目間の関係}

深夜行動間で関係の深い項目を知るために，各項目の平日 の平均行為時間の相関を求めた (Table6). 例えば Table6より, 最も相関の高かった項目（1\%有意）は交際と趣味，家事と 身支度であった．Table6 で有意な相関のあった項目同士を線 で結び，項目間の関係の有無を示したものが Fig.4 である. 図の見方は，例えば，バイトは食事との間に $5 \%$ 有意 $(r=$ $0.230)$ ，移動との間に $5 \%$ 有意 $(r=0.215)$ で相関関係があ り, バイトと直線で結ばれている． Fig.4 より，深夜行動間 の関係は, 移動で結ばれるグループと, 身支度で結ばれるグ ループに大別することができた.移動で結ばれるグループは, 自由行動が多く含まれることから能動グループと考えた。ま た，身支度で結ばれるグループは拘束行為や必需行為で形成 されていることから, 受動グループと考えた. なお有意な相 関関係を持たない項目に，音楽と休息があった。

深夜行動の特徴を考えるには，自由行動が重要であるため, 能動グループについて考察を行う．能動グループの中心にあ る移動は, 有意な相関の項目が 6 個あり最も多く, 行為間の 交差点の役目をしていると考えられる. 移動と直接結びつい ている項目には, 食事, バイト, 趣味, 電話, ショッピング, テレビ（一）がある. これらの項目が相関が高い理由は, 次 の 3 種類に分かれる. 行為に移動が伴う項目 (食事, バイト, 趣味, ショッピング), 行為が移動中に行われる項目 (電話), 及び行為が移動で減少する項目 (負の相関 : テレビ).これら の項目のうち, 梁夜の $\mathrm{n}$ 数が極端に少ない項目（食事, ショ ッピング : Table6 参照) を除くと, バイト, 電話, テレビ (一), 趣味になる．次にこれらの項目を重視，軽視することによる 性格の違いを明らかにする.

\section{6. 被験者グループの性格}

Table7 に，調査 4 項目それぞれについて，重視と軽視の人 数及び両者間に有意差があった性格のみを記載した，その結

Table 7: The tvne of characters for each items

\begin{tabular}{|c|c|c|l|}
\hline item & measure & $n$ & Character \\
\hline \multirow{2}{*}{ work } & inportance & 57 & Optimistic \\
\cline { 2 - 4 } & slight & 20 & \\
\hline \multirow{2}{*}{ hobby } & inportance & 83 & Progressive, frank \\
\cline { 2 - 4 } & slight & 17 & \\
\hline \multirow{2}{*}{ phone } & inportance & 58 & \\
\cline { 2 - 4 } & slight & 32 & \\
\hline \multirow{3}{*}{ TV } & inportance & 51 & warm, dupe \\
\cline { 2 - 4 } & slight & 39 & $\begin{array}{l}\text { passion, progressive, } \\
\text { stubborn, weak, } \\
\text { selfassertive }\end{array}$ \\
\hline
\end{tabular}

果, 深夜に重要な項目を重視すると答えた被験者の特徴は, バイトが楽天的, 趣味が進歩的, さっぱりしている, テレビ が温かい, お人好しであった。一方, 軽視する人は, テレビ
が情熱的, 進歩的, がんこ，気が弱い，わがままであった. この結果, 能動グループに属する行為を行うバイト, 趣味を 重視し, テレビを軽視する（負の相関の）被験者の性格は, 自己主張が強く（わがまま，がんこ，情熱的），前向きの（楽 天的，進歩的，さっぱり）性格であるといえる.

以上の結果から，深夜行動の中心になる能動グループの行 動項目を重視する若者の性格が得られた。 今後, 哚夜行動が 増加するに従い，これらの性格を持つ若者はトレンドリーダ 一になると予測される。したがって，これらの性格を持つ被 験者について購買行動，生活意識等を調べれば，新しいマー ケットの創造が可能になると考えられる.

\section{5. まとめ}

本報告において得られた主な成果は次の通りである.

（1）使用したデータは，個人内の日々の差より，個人閒の 差が大であった。

（2）深夜の行為時間は，全国平均行為時間に比べ，本報告 の平均行為時間の方が長かった．休日の起床者率は平日の約 2 倍高く, 平日より休日の方が深夜化が進んでいた.

（3）就寝時間と終日の生活行動に相関が見られたのは, 自 由行動の項目であった. 拘束行動は終日の生活行動に関係が 無く, 必需行動は半々であった.

（4）深夜行動は 5 つの因子で分類された. 因子の特徴は, 電話, 対話などコミュニケーションのタイプで説明された.

（5）行動時間帯が媣夜に集中している項目は, 電話, コン ピュータ, 休息であった. 深夜行動率の低い項目は, バイト， 移動，ショッピングであった．休日は平日に比べ，深夜行動 率が低かった，梁夜行動率は必需行動，拘束行動に比べ自由 行動で高かった.

（6）深夜行動間の関連を得た。各行動は，移動と身支度を 中心とするグループでまとめられた.このグループのうち, 移動を中心とする能動グループ（自由行動）の被験者の性格 を調べた結果, 自己主張が強く, 前向きのタイプであること が明らかとなった。

注

1 ) NHK世論調查部編: 日本人の生活時間 1990, 日本放 送出版協会, $140,160,170,1992$

2 ）日本家政学会編：日本人の生活, 建帛社, 405, 438, 1998

3 ） NHK 放送文化研究所:NHK 国民生活時間調查 2000 《全

国〉, 102-113, 2001

4 ) 三矢恵子, 吉田理恵: NHK放送文化調查研究年報, $42,182,185,1997$

5 ) 矢野真和: 生活時間の社会学, 東京大学出版会

6 ）本田聆吉: 日本消費経済学会年報, $18,191,1996$ 